\title{
Analysis of the Expression Pattern of microRNA of KSHV in KSHV-infected Human Cells
}

\author{
Sil Kim, Jaehyuk Jang, Myung-Shin Lee and Seung-Min Yoo* \\ Department of Microbiology and Immunology, Eulji University School of Medicine, Yongdu-dong, Jung-gu, \\ Daejeon, Korea
}

\begin{abstract}
Kaposi's sarcoma associated herpesvirus (KSHV) is subdivided into gamma-herpesvirus and causes Kaposi's sarcoma in human immunodeficiency virus (HIV)-infected patients. A defining feature of herpesviral biology is the presence of two alternative genetic lifestyles - a latent infection and a lytic replicative cycle. Almost all herpesviruses examined so far have been shown to express viral miRNAs in latently and/or productively infected cells. KSHV encodes an array of 15 distinct miRNAs, all of which are expressed at readily detectable levels in latently KSHV infected cells. The expression of an array of these viral miRNAs in KSHV-infected cells suggests that down-regulation of host cell mRNAs by miRNA-mediated RNA interference may represent a critical step in the establishment and/or maintenance of latent infections by KSHV. To investigate KSHV miRNAs that are expressed in KSHV-infected cells, KSHV-infected human umbilical cord vein endothelial cells (HUVECs) and BCBL-1 cells were used and their miRNAs were analyzed by a modified real-time PCR method. Some KSHV miRNAs were detected in KSHV-infected HUVECs and their expression was affected by genetic life cycles. In addition, KSHV miRNAs were also detected in BCBL-1 and their expression was not related to treatment of sodium butyrate. These results indicate that KSHV infection in cells inducing KSHV miRNAs expression would be increased upon entry into latent replication.
\end{abstract}

Key Words: KSHV, miRNA, Latent replication

\section{서 론}

RNA는 그 종류가 다양하여 단백질을 합성하는데 필 요한 rRNA와 tRNA 외에도 단백질 합성과 관련이 없 는 다양한 종류의 RNA가 세포 내에서 전사된다. 단백질 합성에 직접 관여하지 않는 이러한 종류의 RNA로는 small nuclear RNA (snRNA), small nucleolar RNA (snoRNA), micro RNA (miRNA), short interfering RNA (siRNA) 등이 있 다 (1). miRNA는 전사(transcription)와 해독(translation) 수
준에서 유전자 발현을 조절할 수 있는 20 22 nucleotide single-stranded non-coding RNA로 messenger RNA (mRNA) 의 $3^{\prime}$ untranslated region (3'UTR)에 결합하여 그 mRNA의 유전암호 해독을 억제하거나 mRNA 자체를 파괴하여 유 전자의 기능을 억제함으로써 생체 내 효과를 나타낸다 $(2$, 3). 숙주 miRNA는 세포주기, 분화, 발열, 대사, patterning 및 노화와 같은 근본적인 생물학적 과정에 관여한다. miRNA의 발현 이상은 여러 종류의 암이나 심장비대, 부 정맥과 같은 심혈관 질환 등의 발병에 중요한 역할을 함 이 알려져 종양학이나 순환기학 등의 분야에서도 활발한

Received: November 5, 2013/ Revised: November 19, 2013/ Accepted: November 27, 2013

* Corresponding author: Seung-Min Yoo. Department of Microbiology and Immunology, Eulji University School of Medicine, Yongdu-dong, Jung-gu, Daejeon, 301-768, Korea.

Phone: +82-42-259-1661, Fax:+82-42-259-1669, e-mail: smyoo@eulji.ac.kr

** This work was supported by the National Research Foundation of Korea (NRF) grant funded by the Korea government (MEST) (No. 2010-0005880).

(c) This is an Open Access article distributed under the terms of the Creative Commons Attribution Non-Commercial License (http://creativecommons.org/license/by-nc/3.0/). 
연구가 이루어지고 있다 (4).

숙주와 마찬가지로 herpesvirus를 비롯한 일부 virus들 도 miRNA를 encoding하고 있다. 최근에 $\gamma$-herpesvirus인 Epstein-Barr virus $(\mathrm{EBV})$ 에 감염된 사람 $\mathrm{B}$ 림프구에서 viral miRNA가 생성된다는 사실이 밝혀졌고, 뒤이어 다 른 herpesvirus에 의해서도 miRNA가 발현된다는 사실이 밝혀짐에 따라 virus의 숙주 감염 중 miRNA의 역할에 대한 중요성이 인식되어 가고 있다 $(5,6)$. 바이러스의 miRNA가 자신이나 숙주의 mRNA를 억제하는 방법은 2 가지이다. 첫째는 바이러스의 miRNA가 자신의 DNA에 서 전사된 상보적인 mRNA에 결합하여 그 발현을 저해 하는 것이고, 둘째는 바이러스의 miRNA가 숙주 mRNA 의 $3^{\prime} \mathrm{UTR}$ 에 결합하여 숙주의 mRNA가 발현되는 것을 억 제하는 것이다 $(7,8)$. 특히 바이러스 miRNA는 면역에 관 련된 유전자를 억제시켜 면역 회피작용을 일으키거나 혹 은 cell cycle을 조절하여 감염된 세포의 수명을 연장시킴 으로써 숙주의 발병을 촉진시킨다 (9 14).

KSHV는 감마 herpes 바이러스의 하나로서, 후천성 면 역 결핍증 환자에게서 발생한 카포시육종에서 분자생물 학적 방법을 통해 처음 발견되었다. KSHV는 카포시육종 외에도 pleural effusion lymphoma (PEL), 다발성 Castleman disease 등의 발생에 중요한 역할을 한다는 사실이 밝혀졌 다 (15 17). KSHV는 lytic phase와 latent phase의 두 가지 생활사로 구성되어 있다. Latent phase에서는 viral genome 이 세포 내 존재하지만 유전자 발현이 제한되고 숙주가 인식하지 못한다. Lytic phase에서는 모든 바이러스 유전 자들이 발현되고 세포 사멸과 progeny virus의 생산을 유 도한다 (18 24).

KSHV도 miRNA를 발현하는데 이들은 숙주세포의 mRNA나 바이러스 자체의 mRNA 발현을 억제함으로써 $\mathrm{KSHV}$ 감염을 유지시키고 확립시키는 중요한 역할을 하 는 것으로 여겨지고 있다. 예를 들어 miR-K12-5와 miRK12-9는 apoptosis를 유발하는 transcriptional repressor인 Bcl-2-associated factor 1 (BCLAF1)의 발현을 억제시켜 세 포사멸 과정(apoptosis pathway)을 조절하고, miR-K12-1은 cell cycle과 관련 있는 Thrombospondin 1 (THBS1)과 p21 의 발현을 억제시켜 감염세포의 성장과 증식에 관여한다 $(25,26)$. 또한 최근에는 KSHV miRNA가 latent phase에서 lytic phase로의 전환을 매개하는 replication and transcription activator (RTA)가 발현하는 것을 억제시켜 latent phase를 유지시킴으로써 바이러스의 life cycle을 조절할 것이라
는 가설이 제기되고 있다 (27). KSHV의 miRNA는 latent replication 시 발현되는 유전자로 알려져 있으나 실제 바 이러스 감염 후, 혹은 lytic replication 유도 후 각각의 miRNA의 발현 변화에 대한 분석은 아직까지 보고된 바 가 없다. 본 연구에서는 사람제대혈정맥내피세포(human umbilical cord vein endothelial cells, HUVECs)과 BCBL-1 세 포를 사용하여 KSHV의 life cycle에 따른 miRNA의 발현 변화를 측정하여 $\mathrm{KSHV}$ 의 생명 활동에 대한 이해를 증진 시키고 $\mathrm{KSHV}$ 감염과 이로 인한 종양의 발병을 억제시 키는 치료 방법의 개발에 대한 기반 지식을 제공하고자 한다.

\section{재료 및 방법}

HUVECs 및 BCBL-1 세포 배양

HUVECs (Clonetics, Walkersville, MD, USA)은 human endothelial growth factor, human fibroblast growth factor B, vascular endothelial growth factor, ascorbic acid, hydrocortisone, long R3-IGF-1, 그리고 heparin을 포함하는 endothelial cell growth medium (BulletKit; Clonetics)에 배양하였다. 사람 임파종 세포주인 BCBL-1 세포는 $10 \%$ fetal bovine serum (FBS; Sigma, St. Lowis, MO, USA), $50 \mu \mathrm{g} / \mathrm{ml}$ 의 gentamicin, $2 \mathrm{mM}$ 의 glutamine을 포함하는 RPMI 1640 배지에 배양 하여 $37^{\circ} \mathrm{C}, 5 \% \mathrm{CO}_{2}$ 항온항습 배양기에서 세포를 유지시 켰다.

\section{HUVECs에 KSHV 감염}

재조합 KSHV인 KSHV-BAC36를 지닌 BCBL-1 세포를 hygromycin으로 선별하여 배양한 후, sodium butyrate를 사 용하여 KSHV 용원성 복제를 유도하였다. 72시간 동안 sodium butyrate 처리 후, 바이러스를 농축하였다. 바이러 스 농축을 위해 sodium butyrate가 처리된 세포 배양액을 $5,000 \times \mathrm{g}$ 로 10 분간 원심 분리하여 세포 및 부산물을 모 두 제거하고 상청액만을 모았다. 상청액을 $20 \%$ sucrose 용액을 사용하여 $100,000 \times \mathrm{g}$ 로 1 시간 동안 초고속 원심 분리 후, pellet을 phosphate buffered saline (PBS)에 녹여 $-70^{\circ} \mathrm{C}$ 에 보관하였다. HUVECs을 6-well plate에 $1 \times 10^{6}$ cell/well로 동일하게 접종한다. 24시간 배양 후에 $5 \mu \mathrm{g} / \mathrm{ml}$ 의 polybrene을 첨가한 바이러스 상청액을 $1 \mathrm{ml} / \mathrm{well}$ 씩 처 리한 뒤 $2,500 \times \mathrm{g}$ 로 60 분간 원심 분리하여 감염시켰다. 바이러스 상청액을 heparin free media로 교환한 뒤 세포 


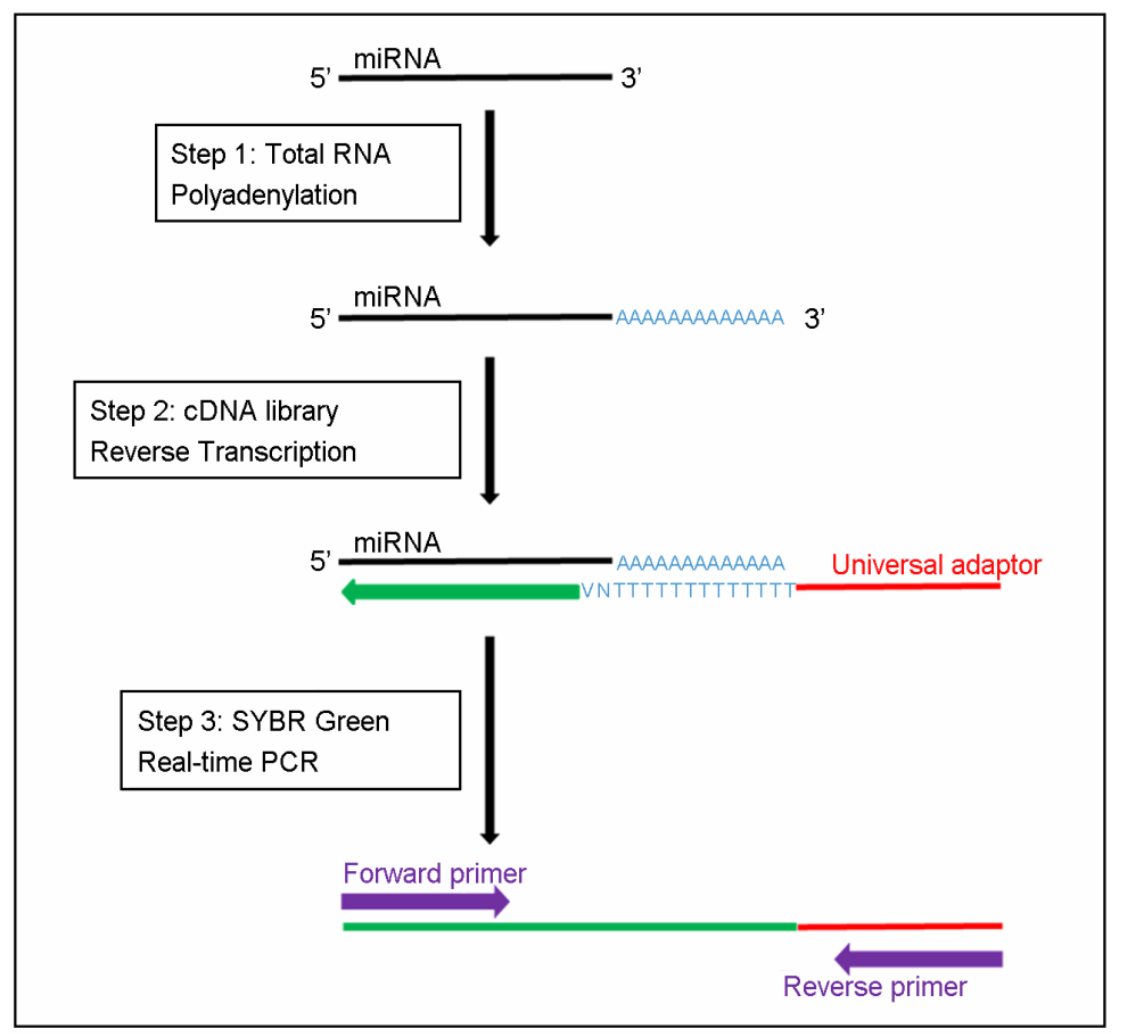

Figure 1. miRNA detection by SYBRpolyA-based techniques. Step 1: polyadenylation of total RNA giving rise to polyadenylated miRNA. Step 2: reverse transcription of poly(A) miRNA using a poly(T) primer that contains a universal adaptor (RACE). Step 3: qPCR amplification using a miRNA-specific forward primer, reverse primer complementary to the universal adaptor.

를 항온항습 배양기에서 배양하였다. 감염 후 $0,24,48$, 72,96 시간 후에 형광현미경으로 $\mathrm{GFP}$ 발현 정도를 관찰 하여 감염 정도를 확인하였다.

\section{$\mathrm{BCBL}-1$ 에 sodium butyrate 처리}

BCBL-1을 T-75 Flask에 $2.1 \times 10^{6}$ cell/flask로 동일하게 접종한 후 sodium butyrate를 처리하고 $0,24,48$ 시간 동안 항온항습 배양기에서 배양하였다.

\section{RNA 추출 및 poly $(A)$ tailing}

$\mathrm{KSHV}$ 감염 후 $0,24,72,96$ 시간 배양시킨 $\mathrm{HUVECs}$ 과 sodium butyrate와 함께 $0,24,48$ 시간 배양시킨 BCBL-1 에서 RNA를 추출하였다. RNA 추출은 RNA isolation kit (MACHERY-NAGEL, Germany)를 이용하였다. 추출한 RNA는 poly(A) tailing kit (Applied Biosystems, Foster City, CA, $\mathrm{USA}$ )를 사용하여 $37^{\circ} \mathrm{C}$ 에서 1시간 동안 polyadenylation 하였고, 반응이 끝난 뒤 $-20^{\circ} \mathrm{C}$ 에 보관하였다.

\section{cDNA 합성 및 Real-time RT PCR}

Universal adaptor인 3' rapid amplification of complementary DNA ends (RACE) adaptor와 poly(T)를 포함하는 RT primer $(2 \mu \mathrm{l})$ 를 poly(A) miRNA $(18 \mu \mathrm{l})$ 와 혼합하고 $85^{\circ} \mathrm{C}$ 에서 2 분간 반응시켰다. 실온에서 10 분간 식힌 뒤 First strand cDNA synthesis kit (TOYOBO, Osaka, Japan)를 사용하여 역 전사 중합효소반응을 통해 $\mathrm{cDNA}$ 를 합성하였다. $\mathrm{KSHV}$ miRNA specific forward primer와 universal adaptor에 상보적 인 reverse primer (RACE primer)를 사용하여 real-time RT $\mathrm{PCR}$ 을 시행하였으며, $\mathrm{PCR}$ 반응의 조성 $(25 \mu \mathrm{l})$ 은 다음과 같다: SYBR Green Realtime PCR Master Mix (TOYOBO, Osaka, Japan) $10 \mu \mathrm{l}$, forward and reverse primer $10 \mu \mathrm{M}$, cDNA template $0.5 \mu$ l. PCR cycle은 역전사 과정을 $37^{\circ} \mathrm{C} 5$ 분, $45^{\circ} \mathrm{C}$ 5 분으로 $5 \mathrm{cycle}$ 시행한 후 $70^{\circ} \mathrm{C}, 10$ 분으로 시행하였다. 그 후 $\mathrm{PCR}$ 증폭을 $95^{\circ} \mathrm{C}, 2$ 분으로 시행한 후 $94^{\circ} \mathrm{C} 20$ 초, $60^{\circ} \mathrm{C} 20$ 초, $72^{\circ} \mathrm{C} 20$ 초로 $45 \mathrm{cycle}$ 을 시행하여 증폭한 뒤 
Table 1. Primers used for reverse transcription and qRT-PCR reactions.

\begin{tabular}{ll}
\hline \hline Primer & \multicolumn{1}{c}{ Sequence } \\
\hline RT1 & 5'-GCGAGCACAGAATTAATACGACTCCTGGGCAATTTTTTTTTTTTVN*-3' \\
RACE1 & 5'-GCGAGCACAGAATTAATACGAC-3' \\
RT2 & 5'-TGTCAGGCAACCGTATTCACCTCCTGCGCAATTTTTTTTTTTTVN*-3' \\
RACE2 & 5'-TGTCAGGCAACCGTATTCACC-3' \\
GAPDHF & 5'-GAAGGTGAAGGTCGGAGTC-3' \\
GAPDHR & 5'-GAAGATGGTGATGGGATTTC-3' \\
\hline
\end{tabular}

$* \mathrm{~V}=\mathrm{A}, \mathrm{G}, \mathrm{C} ; \mathrm{N}=\mathrm{A}, \mathrm{T}, \mathrm{G}, \mathrm{C}$.

Table 2. KSHV miRNA forward primers.

\begin{tabular}{ll}
\hline \hline KSHV miRNA & KSHV miRNA-specific primer \\
\hline KSHV-miR-K12-1 & 5'-ATTACAGGAAACTGGGTGTAAGC-3' \\
KSHV-miR-K12-2 & 5'-AACTGTAGTCCGGGTCGATCTG-3' \\
KSHV-miR-K12-3 & 5'-TCACATTCTGAGGACGGCAGCGA-3' \\
KSHV-miR-K12-4-3p & 5'-TAGAATACTGAGGCCTAGCTGA-3' \\
KSHV-miR-K12-4-5p & 5'-AGCTAAACCGCAGTACTCTAG-3' \\
KSHV-miR-K12-5 & 5'-TAGGATGCCTGGAACTTGCCGG-3' \\
KSHV-miR-K12-6-3p & 5'-TGATGGTTTTCGGGCTGTTGAG-3' \\
KSHV-miR-K12-6-5p & 5'-CCAGCAGCACCTAATCCATCGG-3' \\
KSHV-miR-K12-7-3p & 5'-TGATCCCATGTTGCTGGCGCT-3' \\
KSHV-miR-K12-7-5p & 5'-AGCGCCACCGGACGGGGATTTATG-3' \\
KSHV-miR-K12-8-3p & 5'-CTAGGCGCGACTGAGAGAG-3' \\
KSHV-miR-K12-8-5p & 5'-CTCCCTCACTAACGCCCCGC-3' \\
KSHV-miR-K12-9-3p & 5'-CTGGGTATACGCAGCTGCGTA-3' \\
KSHV-miR-K12-9-5p & 5'-ACCCAGCTGCGTAAACCCCGCT-3' \\
KSHV-miR-K12-10 & 5'-TAGTGTTGTCCCCCCGAGTGGC-3' \\
\hline
\end{tabular}

melting curve 분석을 시행하였다. 1 cycle의 melting curve program은 $65^{\circ} \mathrm{C}$ 에서 $95^{\circ} \mathrm{C}$ 까지 1 초당 $0.2^{\circ} \mathrm{C}$ 씩 증가하는 방식으로 구성하였다(Fig. 1). 모든 sample은 각각의 primer 쌍마다 triplicate로 진행하였으며 각각의 실험은 nontemplete control (NTC)과 internal glyceraldehydes 3-phosphate dehydrogenase (GAPDH) amplification control을 같이 시행 하였다. 이 실험에 사용된 모든 primer는 GENOTECH (Daejeon, Korea)에서 설계 주문하였다(Tables 1 and 2).
결 과

HUVECs에 KSHV-BAC36 감염

재조합 KSHV인 KSHV-BAC36는 숙주세포에 감염될 때 green fluorescence가 발현되도록 설계되었기 때문에 감 염된 $\mathrm{HUVEC}$ 에서 $\mathrm{GFP}$ 발현을 측정함으로써 감염력을 확인하였다(Fig. 2A). GFP 발현은 감염 후 $24,48,72,96$ 시 간 후 각각 측정하였고 전 시간대에서 발현을 확인할 수 있었다. 감염 후 24 시간에서는 $70 \%$ 이상의 cell에서 $\mathrm{GFP}$ 를 발현을 확인할 수 있었지만 시간이 지남에 따라 GFP 
(A)

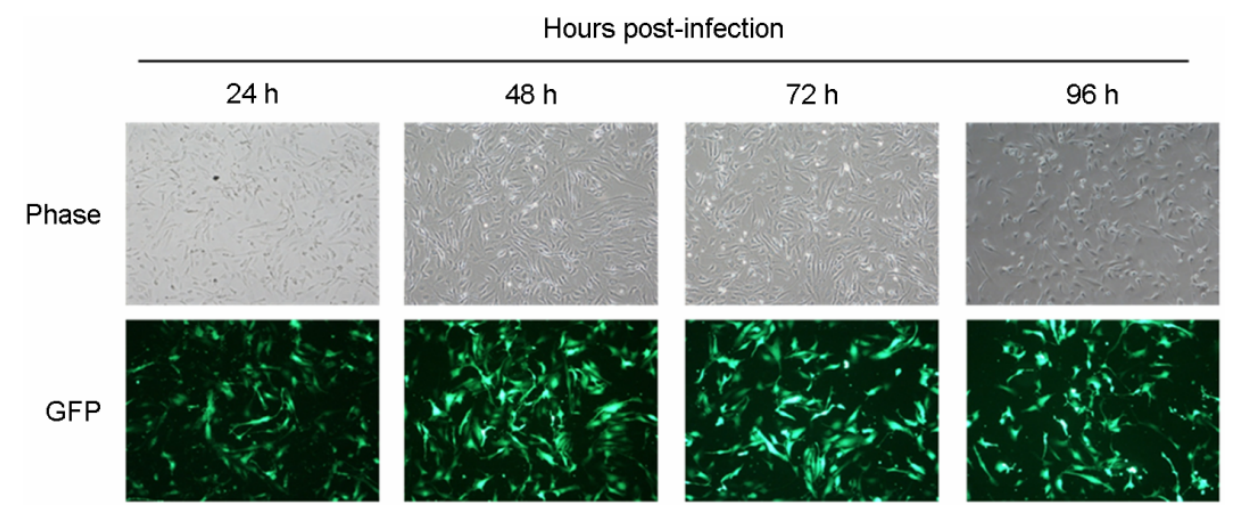

B

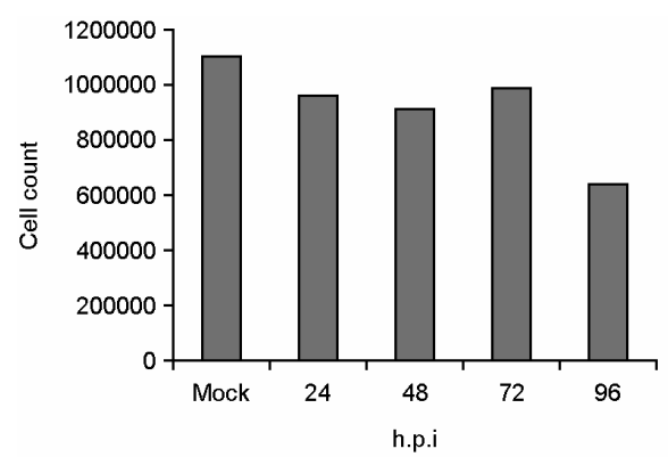

C

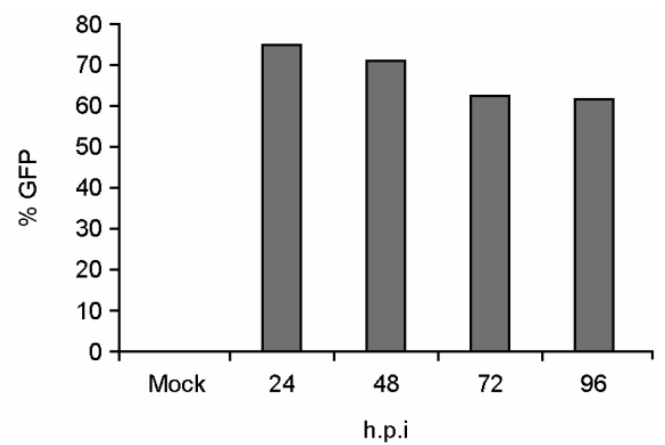

Figure 2. KSHV-BAC36 infection of HUVECs. KSHV-BAC36 infected to each cell by low speed centrifugation with $5 \mu \mathrm{g} / \mathrm{ml}$ of polybrene. After incubation, GFP expression under a fluorescence inverted microscope was evaluated to monitor infection. (A) GFP expression of KSHV-BAC36 infected HUVECs. (B) Cell numbers of HUVECs after KSHV-BAC36 infection were counted. (C) Percentage of GFP expressing cell of remaining cells.

발현 세포의 수는 점점 줄어드는 양상을 보였다. 한편 똑 같은 수로 배양한 $\mathrm{HUVEC}$ 은 감염시킨 후 시간이 지남에 따라 점점 줄어드는 양상을 보였다(Fig. $2 \mathrm{~B}$ and $2 \mathrm{C}$ ). 한 편 KSHV-BAC36에 감염된 $\mathrm{HUVEC}$ 은 방추형 모양으로 형태학적 변화를 나타내었다.

\section{$\mathrm{KSHV}-\mathrm{BAC} 36$ 에 감염된 $\mathrm{HUVEC}$ 에서의 $\mathrm{KSHV}$} miRNAs 발현 양상

KSHV-BAC36에 감염된 HUVEC에서 KSHV miRNAs의 발현 양상을 reverse transcription quantitative real-time PCR 을 통해 확인하였다. 감염 후 각각 $0,24,48,72,96$ 시간 후 총 15 종류의 KSHV miRNAs의 발현 변화를 관찰하였 다. 전반적으로 감염 후 72 시간까지는 낮은 수준에서 발 현되다가 72 96시간에서 발현이 급격히 증가되는 것을 볼 수 있었다(Fig. 3). miR-K12-9-3p는 발현을 확인할 수 없었다. Melting curve 분석을 통해 봤을 때 동일한 melting peak가 관찰되었고 $2 \%(\mathrm{wt} / \mathrm{vol})$ agarose gel 전기영동을 통해 PCR 증폭 산물을 다시 확인했을 때 $100 \mathrm{bp}$ 미만에 서 동일한 밴드가 형성되는 것을 볼 수 있었다(data not shown).

Sodium butyrate를 처리한 $\mathrm{BCBL}-1$ 에서의 $\mathrm{KSHV}$ miRNAs 발현 양상

Sodium butyrate를 처리하여 용원성 복제를 유도한 BCBL-1에서 KSHV miRNAs의 발현 양상을 reverse transcription quantitative real-time $\mathrm{PCR}$ 을 통해 확인하였다. 처 리 후 각각 $0,24,48$ 시간 후 총 15 종류의 KSHV miRNAs 의 발현 변화를 관찰하였다. Fig. 3 에서 HUVEC에 감염시 키는 경우는 KSHV 감염 후 lytic replication을 유도한 후 latent로 넘어가는 변화를 보기 위해 96시간까지 관찰하 였으나, $\mathrm{BCBL}-1$ 의 경우 이미 KSHV가 감염되어 latent replication 상태를 유지하고 있는 상태에서 lytic replication 
miR-K12-1
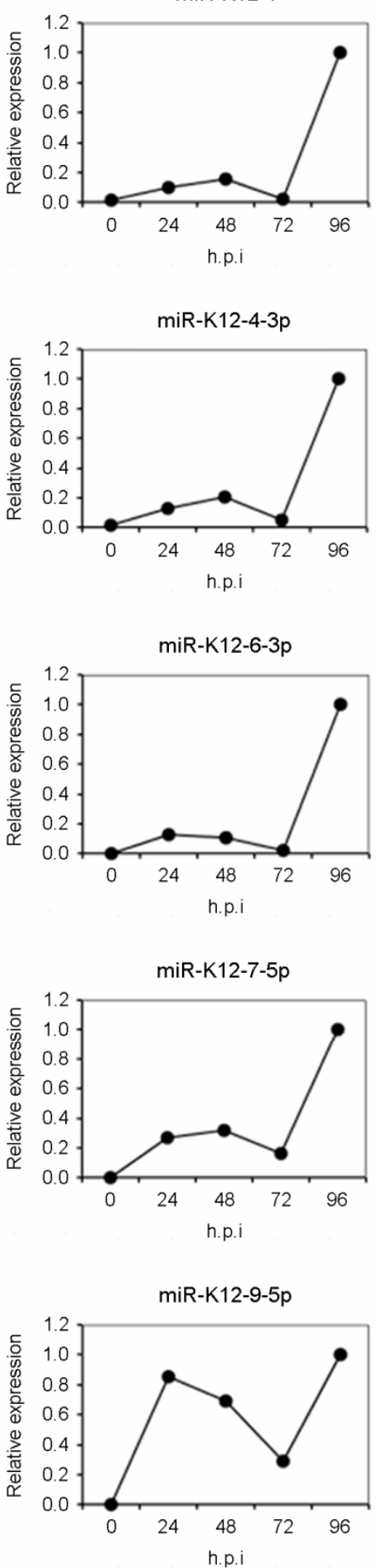

$\mathrm{miR}-\mathrm{K} 12-2$
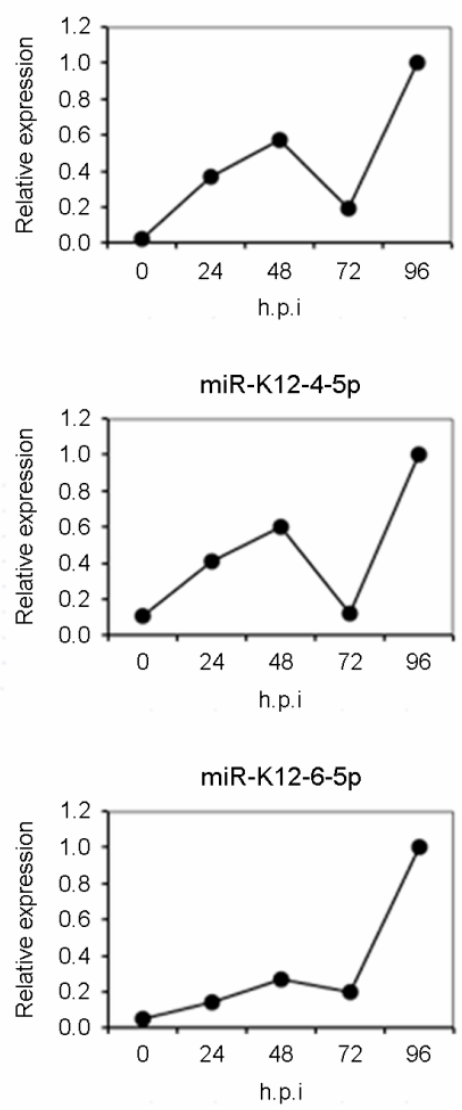

miR-K12-8-3p

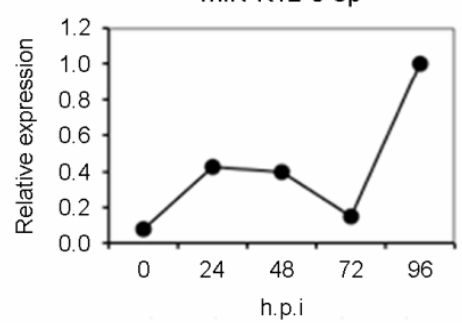

miR-K12-10

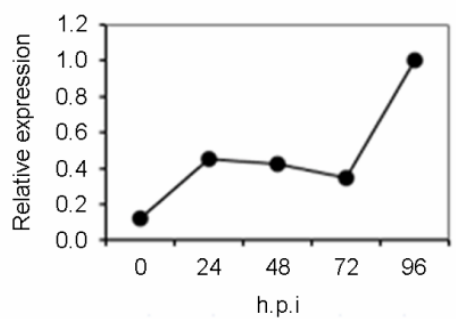

miR-K12-3

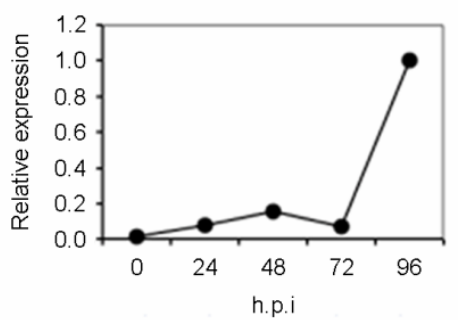

miR-K12-5

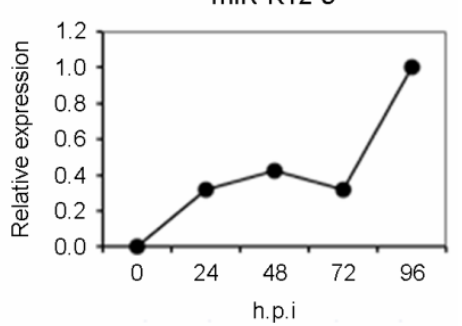

miR-K12-7-3p

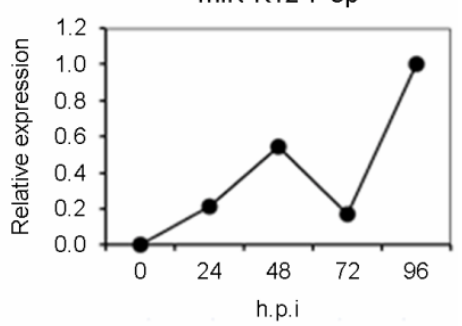

miR-K12-8-5p

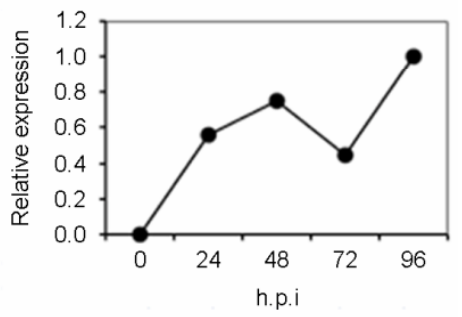

Figure 3. Expression kinetics of KSHV miRNAs after infection of HUVECs with KSHV. The expression levels of KSHV miRNAs at each time points were measured by quantitative real-time RT-PCR method. The graphs show relative amounts of KSHV miRNAs expression at each time points compared with their maximum expression amounts. KSHV miRNAs were detected in KSHV-infected HUVECs and their expression was affected by genetic life cycle. 

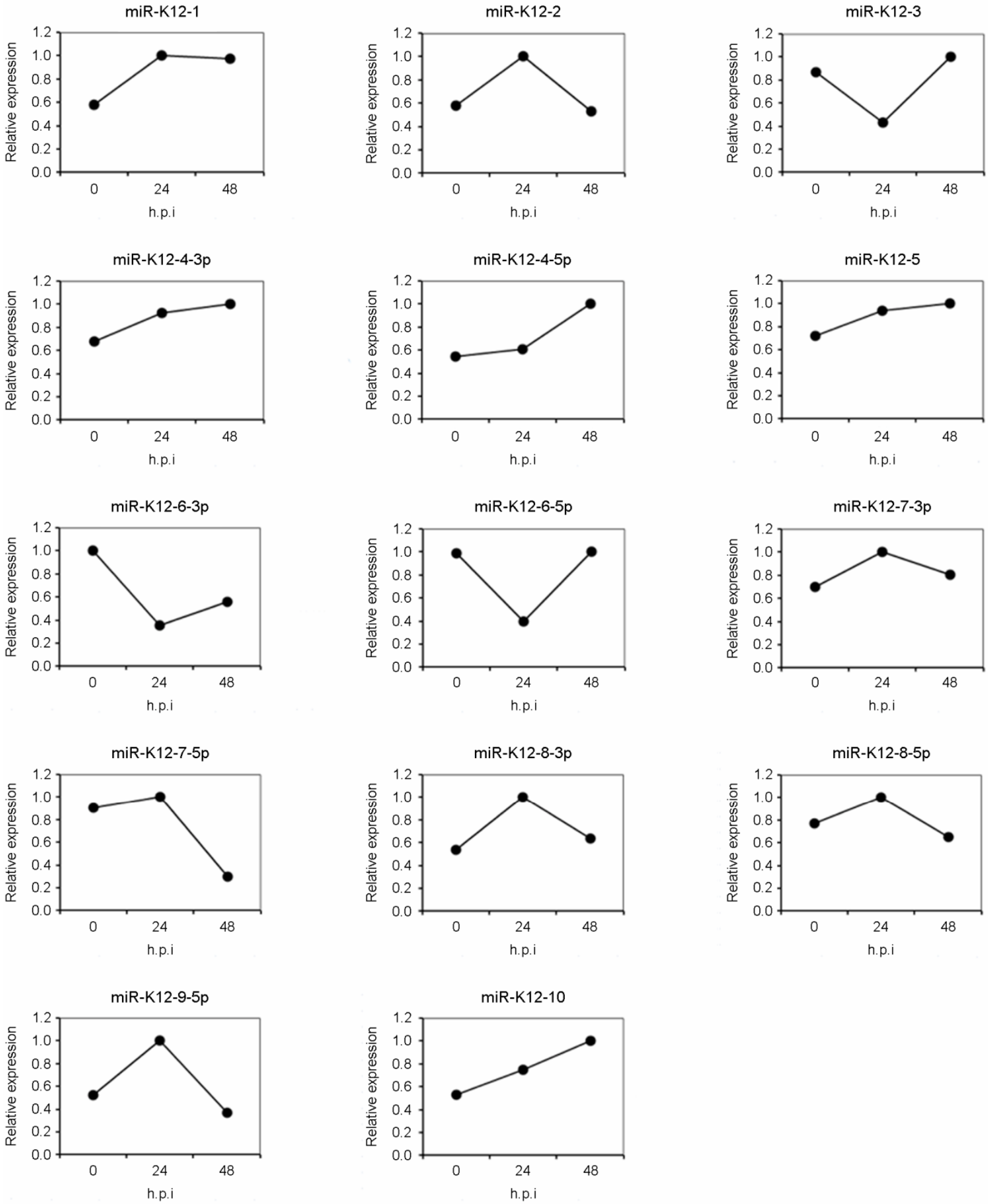

Figure 4. Expression kinetics of KSHV miRNAs after treatment of sodium butylate on BCBL-1. The expression levels of KSHV miRNAs at each time points were tested by quantitative real-time RT-PCR method. The graphs show relative amounts of KSHV miRNAs expression at each time points compared with their maximum expression amounts. KSHV miRNAs were detected in BCBL-1 and their expression has no relationship to the treatment of sodium butylate. 
을 유도하는 것이기 때문에 48시간까지만 관찰하였다. Sodium butyrate 처리 유무와 관계없이 KSHV miRNA가 높은 수준으로 발현되었고 시간 별 추이도 일관성을 보 이지 않았다(Fig. 4). miR-K12-9-3p는 발현을 확인할 수 없 었다. Melting curve 분석을 통해 봤을 때 동일한 melting peak가 관찰되었고 $2 \%(\mathrm{wt} / \mathrm{vol})$ agarose gel 전기영동을 통해 PCR 증폭 산물을 다시 확인했을 때 $100 \mathrm{bp}$ 미만에 서 동일한 밴드가 형성됨을 알 수 있었다(data not shown).

\section{고 찰}

본 연구에서 $\mathrm{KSHV}$ 에 감염된 $\mathrm{HUVECs}$ 에서 감염 후 시간에 따른 $\mathrm{KSHV}$ miRNA의 발현 양상과 $\mathrm{KSHV}$ 에 잠 복 감염된 $\mathrm{BCBL}-1$ 에서 용혈성 복제 유도제인 sodium butyrate 처리 후 시간에 따른 KSHV miRNA의 발현 양상 을 확인하였다. HUVEC에 KSHV 감염 후 miR-K12-1, -3, $-7,-8,9,-10$ 은 48 시간까지 발현이 낮은 상태를 유지하다 가 96 시간에 증가하는 패턴을 보인 반면, 나머지 miRNA 들은 48 시간까지 발현이 증가하다가 72 시간에 낮아진 후 다시 96시간에 증가하는 패턴을 나타내었다. 초기에 48 시간까지는 lytic replication이 점차적으로 증가하는 시기 이므로 miR-12-2, $-6,-8,-9$ 와 같이 초기에 발현이 증가되 는 miRNA들은 lytic replication의 영향을 받는 것으로 보 인다. 그러나 $\mathrm{KSHV}$ 에 감염된 $\mathrm{HUVECs}$ 에서 모든 miRNA 들이 72 96시간대에서 급격히 발현이 증가되었다. 이 시 간대는 lytic phase에서 latent phase로 넘어가는 시점으로 결과적으로 $\mathrm{KSHV}$ miRNA가 latent phase에서 높게 발현 된다고 볼 수 있다. $\mathrm{KSHV}$ 에 잠복 감염된 $\mathrm{BCBL}-1$ 에서 sodium butyrate 처리 유무와 상관없이 KSHV miRNA가 높게 발현된다는 사실이 이를 다시 한번 입증한다. 이처 럼 latent phase에서 KSHV miRNA의 발현이 높게 나타나 고 이는 곧 $\mathrm{KSHV}$ miRNA가 latent phase에서 뭔가 역할을 할 것이라는 추측을 가능케 한다. 실제로 최근에 다양한 herpesvirus의 viral miRNA들이 latent-lytic switch를 조절 한다는 연구 결과들이 나오고 있다 (28). 예를 들어 HSV 와 $\mathrm{HCMV}$ 에 관한 연구에서 viral miRNA가 lytic replication 에 필요한 immediate-early gene의 발현을 조절한다는 결 과를 얻어, viral miRNA와 생활사의 연관성을 뒷받침하 였다. 하지만 다루기 쉬운 세포 감염 모델이 없어 이들의 기능적인 역할을 알기가 쉽지 않다. 반면 $\mathrm{KSHV}$ 는 감염 모델이 확립되어 있어 miRNA에 관한 다양한 연구들이
수행되고 있다. 예를 들어 $\mathrm{KSHV}$ 의 miR-K5가 숙주의 BCLAF-1 유전자의 발현을 조절하여 latent-lytic switch에 영향을 준다는 연구 결과와 miR-K9는 latent에서 lytic으 로 reactivation을 조절하는 major lytic switch protein (RTA) 를 targeting하여 발현을 억제함으로써 latent phase를 유지 시킨다는 결과도 있다 (27). 이는 KSHV miRNA가 viral miRNA를 조절함으로써 궁극적으로는 숙주의 면역반응 을 조절하기 위한 것으로 보인다. 즉 latent phase 상태를 유지시킴으로써 숙주의 면역반응을 회피하고자 하는 것 이다. HUVECs에서와는 달리 BCBL-1에서 lytic replication 을 유도시킨 이후에 miRNA의 발현은 각각의 miRNA에 따라 다르게 이루어졌다. miR12-1, $-4,-5,-10$ 은 점차적으 로 증가하고, $-2,-7,-8,-9$ 는 증가 후 감소, $-3,-6$ 은 감소 후 증가하는 패턴을 나타내었다. 이는 각각의 miRNA가 lytic replication에서 각각 다른 역할을 할 가능성을 보여 주고 있으며, 혈관내피세포와 림프구에서 miRNA에 의한 $\mathrm{KSHV}$ 감염 조절이 다른 방식으로 이루어질 가능성을 시 사해 준다. 이러한 가설을 보다 확고히 하기 위해 앞으로 miRNA deletion mutant virus, 동물 실험모델 등을 사용한 추가적인 연구가 이루어져야 할 것으로 생각된다.

\section{REFERENCES}

1) Lodish HF. Molecular cell biology. 6th ed. New York, WH Freeman \& Co, 2007.

2) Lai E. Micro RNAs are complementary to 3' UTR sequence motifs that mediate negative post-transcriptional regulation. Nat Genet 2002;30:363-4.

3) Bartel DP. MicroRNAs: Genomics, Biogenesis, Mechanism, and Function. Cell 2004;116:281-97.

4) Ji JD, Kim TH. Rheumatoid Arthritis and microRNA. J Korean Rheum Assoc 2010;17:230-7.

5) Boss IW, Renne R. Viral miRNAs: tools for immune evasion. Curr Opin Microbiol 2010;13:540-5.

6) Cullen BR. Viral and cellular messenger RNA targets of viral microRNAs. Nature 2009;457:421-5.

7) Bartel DP. MicroRNAs: target recognition and regulatory functions. Cell 2009;136:215-33.

8) Filipowicz W, Bhattacharyya SN, Sonenberg N. Mechanisms of post-transcriptional regulation by microRNAs: are the answers in sight? Nat Rev Genet 2008;9:102-14.

9) Qin Z, Kearney P, Plaisance K, Parsons CH. Pivotal advance: 
Kaposi's sarcoma-associated herpesvirus (KSHV)-encoded microRNA specifically induce IL-6 and IL-10 secretion by macrophages and monocytes. J Leukoc Biol 2010;87:25-34.

10) Nachmani D, Stern-Ginossar N, Sarid R, Mandelboim O. Diverse herpesvirus microRNAs target the stress-induced immune ligand MICB to escape recognition by natural killer cells. Cell Host Microbe 2009;5:376-85.

11) Seo GJ, Fink LH, O'Hara B, Atwood WJ, Sullivan CS. Evolutionarily conserved function of a viral microRNA. J Virol 2008;82:9823-8

12) Stern-Ginossar N, Elefant N, Zimmermann A, Wolf DG, Saleh $\mathrm{N}$, Biton $\mathrm{M}$, et al. Host immune system gene targeting by a viral miRNA. Science 2007;317:376-81.

13) Sullivan CS, Grundhoff AT, Tevethia S, Pipas JM, Ganem D. SV40-encoded microRNAs regulate viral gene expression and reduce susceptibility to cytotoxic T cells. Nature 2005; 435:682-6.

14) Xia T, O'Hara A, Araujo I, Barreto J, Carvalho E, Sapucaia JB, et al. EBV microRNAs in primary lymphomas and targeting of CXCL-11 by ebv-mir-BHRF1-3. Cancer Res 2008;68:1436 -42 .

15) Cesarman E, Chang Y, Moore PS, Said JW, Knowles DM. Kaposi's sarcoma-associated herpesvirus-like DNA sequences in AIDS-related body-cavity-based lymphomas. N Engl J Med 1995;332:1186-91.

16) Chang Y, Cesarman E, Pessin MS, Lee F, Culpepper J, Knowles DM, et al. Identification of herpesvirus-like DNA sequences in AIDS-associated Kaposi's sarcoma. Science 1994;266:1865 -9 .

17) Soulier J, Grollet L, Oksenhendler E, Cacoub P, Cazals-Hatem $\mathrm{D}$, Babinet $\mathrm{P}$, et al. Kaposi's sarcoma-associated herpesviruslike DNA sequences in multicentric Castleman's disease. Blood 1995;86:1276-80

18) Blasig C, Zietz C, Haar B, Neipel F, Esser S, Brockmeyer NH, et al. Monocytes in Kaposi's sarcoma lesions are productively infected by human herpesvirus 8. J Virol 1997;71:7963-8.

19) Davis MA, Stürzl M, Blasig C, Schreier A, Guo HG, Reitz M, et al. Expression of human herpesvirus 8-encoded cyclin $\mathrm{D}$ in
Kaposi's sarcoma spindle cells. J Natl Cancer Inst 1997;89: 1868-74.

20) Dupin N, Fisher C, Kellam P, Ariad S, Tulliez M, Franck N, et al. Distribution of human herpesvirus- 8 latently infected cells in Kaposi's sarcoma, multicentric Castleman's disease, and primary effusion lymphoma. Proc Natl Acad Sci U S A 1999; 96:4546-51.

21) Kirshner JR, Staskus K, Haase A, Lagunoff M, Ganem D. Expression of the open reading frame 74 (G-protein-coupled receptor) gene of Kaposi's sarcoma (KS)-associated herpesvirus: implications for KS pathogenesis. J Virol 1999;73:6006 -14 .

22) Orenstein JM, Alkan S, Blauvelt A, Jeang KT, Weinstein MD, Ganem D, et al. Visualization of human herpesvirus type 8 in Kaposi's sarcoma by light and transmission electron microscopy. AIDS 1997;11: F35-45.

23) Stürzl M, Blasig C, Schreier A, Neipel F, Hohenadl C, Cornali E, et al. Expression of HHV-8 latency-associated T0.7 RNA in spindle cells and endothelial cells of AIDS-associated, classical and African Kaposi's sarcoma. Int J Cancer 1997; 72:68-71.

24) Stürzl M, Hohenadl C, Zietz C, Castanos-Velez E, Wunderlich A, Ascherl G, et al. Expression of K13/v-FLIP gene of human herpesvirus 8 and apoptosis in Kaposi's sarcoma spindle cells. J Natl Cancer Inst 1999;91:1725-33.

25) Ziegelbauer JM, Sullivan CS, Ganem D. Tandem array-based expression screens identify host mRNA targets of virus-encoded microRNAs. Nat Genet 2009;41:130-4.

26) Samols MA, Skalsky RL, Maldonado AM, Riva A, Lopez $\mathrm{MC}$, Baker HV, et al. Identification of cellular genes targeted by KSHV-encoded microRNAs. PLoS Pathog 2007;11:3:e65.

27) Bellare P, Ganem D. Regulation of KSHV lytic switch protein expression by a virus-encoded microRNA: an evolutionary adaptation that fine-tunes lytic reactivation. Cell Host Microbe 2009;6:570-5.

28) Lei X, Bai Z, Ye F, Huang Y, Gao SJ. Regulation of herpesvirus lifecycle by viral microRNAs. Virulence 2010;1:433-5. 